\title{
Pengembangan Konten Website tentang Informasi Karier Berbasis 4C's Bagi Siswa SMKN 2 Malang
}

\author{
Yusrolana Nurilah, Muslihati, Triyono \\ Universitas Negeri Malang, Jl. Semarang No. 5 Malang, Jawa Timur, Indonesia \\ *Penulis korespondensi, Surel: yusrolananurilah96@gmail.com
}

Paper received: 2-1-2021; revised: 23-1-2021; accepted: 30-1-2021

\begin{abstract}
The research was intended to produce a website content about career information for students of SMKN 2 Malang. This creative and innovative website content is student-centered. Today's millennial generation also need to develop 4C's skills in everyday life to prepare for education and employment in the 21st century. Development research adapted into the five steps of Borg and Gall (1983). Trials consist of an initial product trials and limited field trials. An initial product trials were conducted by BK material experts and media experts, while limited field trials were carried out by counselors. The instrument was validated using logical validity based on the aspects of accuracy, usefulness, convenience and attractiveness. Quantitative data were analyzed using an inter-rater agreement, while qualitative data were analyzed using the Miles and Huberman model input from experts and potential product users. The results of the assessment show that website content products have a very high acceptance so that they are suitable for use in BK services regarding 4C's based career information for vocational students. It is hoped that the counselor can provide this information service to students by understanding the infographic as a guide to using the website and adjusting it to the activity procedures on the RPL-BK. For future researchers, it is hoped that they can test the effectiveness of the product in order to obtain more accurate results. In addition, it can also combine with new models or theories to make it more complete and interesting.
\end{abstract}

Keywords: website content; career information services; 4C's skills

\begin{abstract}
Abstrak
Penelitian ini bertujuan untuk menghasilkan konten website tentang informasi karier siswa SMKN 2 Malang. Konten website secara kreatif dan inovatif ini berpusat pada siswa. Generasi millenial zaman sekarang juga perlu mengembangkan keterampilan 4C's pada kehidupan sehari-hari demi mempersiapkan pendidikan dan pekerjan di abad ke-21. Penelitian pengembangan mengadaptasi menjadi lima langkah Borg and Gall (1983). Uji coba terdiri dari uji coba produk awal dan uji lapangan terbatas. Uji coba produk awal oleh ahli materi BK dan ahli media, sedangkan uji lapangan terbatas dilakukan oleh konselor. Instrumen divalidasi dengan menggunakan validitas logika berdasarkan aspek ketepatan, kegunaan, kemudahan dan kemenarikan. Data kuantitatif dianalisis menggunakan inter-rater agreement, sedangkan data kualitatif dianalisis menggunakan model Miles dan Huberman dari masukan para ahli dan calon pengguna produk. Hasil penilaian menunjukkan bahwa produk konten website memiliki keberterimaan yang sangat tinggi sehingga layak digunakan pada layanan BK tentang informasi karier berbasis 4C's bagi siswa SMK. Diharapkan kepada konselor dapat memberikan layanan informasi ini kepada siswa dengan memahami infografis sebagai petunjuk penggunaan website dan disesuaikan pada prosedur kegiatan dalam RPL-BK. Bagi peneliti selanjutnya, diharapkan dapat menguji keefektifan produk guna memperoleh hasil yang lebih akurat. Selain itu, dapat juga dengan mengkombinasikan dengan model atau teori baru agar lebih lengkap dan menarik.
\end{abstract}

Kata kunci: konten website; layanan informasi karier; keterampilan 4C's

\section{Pendahuluan}

Tugas perkembangan remaja sesuai dengan Standar Kompetensi Kemandirian Peserta Didik (SKKPD) adalah sikap dan perilaku dirinya sendiri dalam menyikapi lingkungan 
disekitarnya, salah satunya terkait dengan karier pada masa mendatang. Dengan hal ini dipastikan bahwa siswa membutuhkan layanan bimbingan dan konseling di sekolah. Bimbingan dan konseling bukan suatu kegiatan dalam konteks pembelajaran dengan sistem mengajar layaknya guru bidang studi, melainkan layanan ahli dalam konteks memandirikan peserta didik di sekolah (ABKIN dalam Kamaluddin 2011). Implementasi Bimbingan dan Konseling di sekolah diorientasikan dalam empat bidang BK, diantaranya adalah bidang pribadi, sosial, belajar dan karier. Karier dalam perspektif John Holland yang paling sesuai adalah kepuasan diri akan didapat atas dasar perpaduan antara tipe kepribadian tertentu dengan model lingkungan yang sesuai, untuk menghasilkan keselarasan dan kecocokan okupasional sehingga siswa dapat mengembangkan diri dalam lingkungan karier pendidikan lanjutan ataupun jabatan yang diampu (Afandi, 2011).

Jenis layanan BK yang dapat diterapkan salah satunya melalui layanan informasi karier. Informasi karier paling sering diberikan kepada siswa Sekolah Menengah Kejuruan (SMK). Guna, siswa akan terarah untuk mencapai tujuan yang diinginkannya baik dari segi pilihan karier untuk bekerja maupun melanjutkan pendidikan lanjutan yang lebih tinggi. Meski realitanya masih banyak dari beberapa siswa yang sulit untuk menerima informasi yang telah dijelaskan konselor di kelas pada setiap jam BK. Di sisi lain, layanan informasi karier yang diberikan konselor masih dengan ekspositori atau hanya sebatas informasi lisan didalam kelas. Teknik ekspositori kekurangannya yakni akan menimbulkan banyak persepsi antar siswa dan guru sehingga tidak terlalu efisien dalam melaksanakan layanan BK. Maka dari itu layanan ini perlu dikembangkan dengan faktor penunjang yakni sebuah media yang nantinya dapat diakses oleh siapapun baik warga sekolah (guru dan siswa) maupun warga rumah (orang tua dan saudara).

Media yang sesuai dengan gaya belajar atau perilaku generasi millenial saat ini salah satunya berupa konten website. Media konten website merupakan media yang kreatif dan inovatif sehingga dapat digunakan oleh konselor sebagai faktor penunjang dalam memberikan layanan informasi karier. Selain itu, juga untuk menarik perhatian siswa khususnya siswa SMKN 2 Malang dalam memahami informasi karier terkait lanjut kuliah dan lanjut kerja. Siswa pun akan mudah mengakses konten website dimana saja dan kapan saja dengan menggunakan PC atau laptop yang syaratnya hanya harus terhubung oleh koneksi internet, dikarenakan website merupakan penghubung dokumen dengan fasilitas internet dalam lingkup lokal maupun jarak jauh sekalipun (Hakim, 2004).

Pada abad ke-21, maraknya tantangan untuk mendidik generasi muda dengan memberikan bimbingan baru yang perlu dikembangkan dalam kehidupan, maka dengan hal ini penting salah satunya penerapan keterampilan 4C's yakni mencakup: critical thinking and problem solving (keterampilan berpikir kritis dan menyelesaikan masalah), creative thinking and innovation (keterampilan berpikir kreatif dan inovasi), collaboration (keterampilan kolaborasi) and communication (keterampilan komunikasi). Empat pilar kehidupan tersebut masing-masing mengandung keterampilan khusus yang perlu diberdayakan dalam kegiatan belajar, demi mempersiapkan siswa agar menjadi pribadi yang sukses dalam hidup terutama karier (Zubaidah, 2016). Keterampilan 4C's ini yang akan ditinjau pada media konten website tentang layanan informasi karier bagi siswa SMKN 2 Malang.

Penelitian ini mengacu pada penelitian sebelumnya yang dilakukan oleh : (1) Ari Murdiyanto, Edi Purwanta, dan Kamaruddin dengan judul Pengembangan Layanan Informasi 
Karier Berbasis Media Blog Untuk Meningkatkan Eksplorasi Karier Siswa Di SMP Kota Magelang, tahun 2017; (2) Dwi Anita Agustina dengan judul Pengembangan Paket Layanan Informasi Studi Lanjut pada Sekolah Kedinasan bagi Siswa SMA, tahun 2015; dan (3) Trisma Sulyganistia dengan judul Penerapan Layanan Informasi Karier dengan Menggunakan Media Flashcard untuk Meningkatkan Kemantapan Perencanaan Karier Siswa Kelas XI SMA Negeri 11 Surabaya, tahun 2013. Perbedaan dari penelitian ini dengan beberapa penelitian sebelumnya terletak pada subjek (jenjang atau tahapan pendidikan), objek (materi atau konten yang diteliti), dan produk atau media yang dikembangkan sebagai bentuk layanan BK bagi siswa dan konselor di sekolah. Gagasan atau ide dalam penelitian ini juga berdasarkan hasil wawancara dengan konselor serta adanya hasil observasi di sekolah yang telah disesuaikan dengan angket kebutuhan (need assessment).

Berdasarkan hasil dari beberapa penelitian terdahulu, yakni bertujuan untuk meningkatkan eksplorasi karier dengan adanya informasi yang disesuaikan dengan jenjang pendidikan, guna untuk memantapkan perencanaan karier siswa dengan mengembangkan berbagai macam produk atau media BK. Maka dari itu, pengembang berinisiatif untuk menambah informasi karier terkait lanjut kuliah dan lanjut kerja dengan mengembangkan konten website, sehingga menambah wawasan yang luas khususnya bagi siswa SMK. Dengan demikian, pengembang mengangkat judul "Pengembangan Konten Website Tentang Informasi Karier Berbasis 4C's Bagi Siswa SMKN 2 Malang”. Tujuan dari penelitian pengembangan ini adalah menghasilkan konten website informasi karier siswa SMKN 2 Malang, yang berterima secara teoritik dan praktis berdasarkan aspek ketepatan, kegunaan, kemudahan dan kemenarikan.

\section{Metode}

Metode yang digunakan dalam rancangan penelitian ini mengadaptasi model prosedur penelitian dan pengembangan Borg \& Gall (1983) dengan tahapan yang disesuaikan kondisi dan kebutuhan pengembang. Prosedur penelitian pengembangan ini berdasarkan 5 tahap, yakni (1) Tahap pengumpulan informasi. Pada tahap ini, pengembang menemukan permasalahan yang terjadi di sekolah, melakukan studi pendahuluan berupa wawancara kepada konselor dan angket kebutuhan (need assessment) siswa, dan melakukan studi literatur atau mengkaji bahan pustaka; (2) Tahap perencanaan. Pada tahap ini, pengembang melakukan perencanaan (planning) meliputi kemampuan-kemampuan yang diperlukan dalam pelaksanaan penelitian, rumusan tujuan yang hendak dicapai dalam penelitian, desain atau langkah-langkah penelitian, kemungkinan pengujian dalam lingkup terbatas pada subjek penelitian; (3) Tahap pengembangan produk. Pada tahap ini, pengembang menyusun dan mengembangkan materi informasi karier secara detail melalui website. Selain itu, di dalamnya menyertakan infografis sebagai cara penggunaan website. Produk ini akan menjadi media BK terbaru di SMKN 2 Malang. Selain itu, pengembang juga menyusun alat evaluasi atau instrumen validasi ahli produk (ahli materi dan ahli media) serta calon pengguna produk konten website; (4) Tahap uji coba lapangan awal. Pada tahap ini, pertama, pengembang melakukan validasi ahli yang mencakup ahli materi BK dan ahli media : subjek ( 2 ahli materi BK dan 2 ahli media), instrumen (skala penilaian dan lembar saran), analisis data (kuantitatif dan kualitatif). Kedua, uji lapangan terbatas dilakukan oleh uji calon pengguna (konselor); (5) Tahap merevisi produk utama. Pada tahap ini, pengembang melakukan uji lapangan utama : subjek ( 2 orang konselor), instrumen (skala penilaian dan lembar saran) dan analisis data (kuantitatif dan kualitatif). 
Instrumen yang digunakan adalah penilaian dari validasi ahli materi BK, validasi ahli media dan validasi calon pengguna produk (konselor). Format penilaian memuat berdasarkan kriteria berupa ketepatan, kegunaan, kemudahan dan kemenarikan. Jenis data dalam penelitian pengembangan ini adalah data kuantitatif berupa skor dan kualitatif berupa masukan dari para ahli dan calon pengguna produk (konselor). Data kuantitatif dianalisis menggunakan inter-rater agreement model, sedangkan data kualitatif dianalisis menggunakan Miles dan Huberman. 2000)

Teknik analisis data kuantitatif menggunakan Inter-rater Agreement Model (Gregory,

Tabel 1. Inter-rater Agreement Model

\begin{tabular}{cccc}
\cline { 3 - 4 } & & \multicolumn{2}{c}{$\begin{array}{c}\text { Pendapat Ahli dan Calon Pengguna } \\
\text { Produk (1) }\end{array}$} \\
\cline { 3 - 4 } & & $\begin{array}{c}\text { Relevansi } \\
\text { Rendah (1-2) }\end{array}$ & $\begin{array}{c}\text { Relevansi } \\
\text { Tinggi (3-4) }\end{array}$ \\
\hline $\begin{array}{c}\text { Pendapat Ahli dan } \\
\text { Calon Pengguna Produk } \\
\text { (2) }\end{array}$ & Relevansi Rendah (1-2) & A & B \\
\cline { 2 - 4 } & Relevansi Tinggi (3-4) & C & D \\
\hline
\end{tabular}

Perhitungan validasi ahli materi Bimbingan dan Konseling, ahli media dan calon pengguna dengan menggunakan rumus berikut:

$$
\text { Indeks Uji Ahli }=\frac{D}{A+B+C+D}
$$

Keterangan:

A : Relevansi sangat rendah

B : Relevansi rendah

C : Relevansi tinggi

D : Relevansi sangat tinggi

Hasil dari perhitungan dengan rumus indeks validasi ahli dan calon pengguna produk dapat diklasifikasikan sesuai pada Tabel 2.

Tabel 2. Pengklasifikasian Indeks Validasi Ahli dan Calon Pengguna Produk

\begin{tabular}{cc}
\hline Rentang Skor & Klasifikasi Validitas \\
\hline $0,75-1$ & Sangat Tinggi \\
$0,50-0,74$ & Tinggi \\
$0,25-0,49$ & Rendah \\
$0,00-0,24$ & Sangat Rendah \\
\hline
\end{tabular}

Teknik analisis data kualitatif menggunakan model Miles dan Huberman. Langkahlangkah ini terdiri dari reduksi data, penyajian data, dan penarikan kesimpulan (Miles dan Huberman dalam Sugiyono, 2014). 


\section{Hasil dan Pembahasan}

\subsection{Hasil}

Produk yang dihasilkan pada penelitian dan pengembangan ini adalah konten website tentang informasi karier berbasis 4C's bagi siswa SMKN 2 Malang. Konten website yang dihasilkan merupakan produk untuk siswa agar mendalami informasi karier terkait informasi lanjut kuliah dan lanjut kerja. Konten website tentang informasi karier dibuat dengan tampilan yang menarik serta teknis website yang sederhana demi memudahkan siswa dalam menerima layanan BK. Konten website tentang informasi karier dapat diakses melalui laman "bkmillenial.com". Tampilan website didominasi dengan warna orange dan biru, warna orange dilambangkan dengan harapan, siswa dapat bersemangat, optimis dan percaya diri. Sedangkan warna biru dilambangkan dengan harapan, siswa dapat bertanggung jawab, cerdas dan bijak dalam mengambil keputusan. Icon yang terdapat pada tampilan website juga sudah sesuai dengan materi yang tersampaikan, sehingga membuat siswa lebih bisa memahami makna materi.

Halaman yang ditampilkan terdapat lima menu yakni halaman beranda, yang berisi infografis sebagai panduan penggunaan konten website informasi karier; halaman materi, yang berisi informasi lanjut kuliah dan lanjut kerja; halaman pengembang, yang berisi pengembang utama dan mitra pengembang; halaman chatroom, yang berisi berdiskusi bersama langsung dengan para konselor dan halaman konselor, yang berisi akun konselor dan profil konselor.

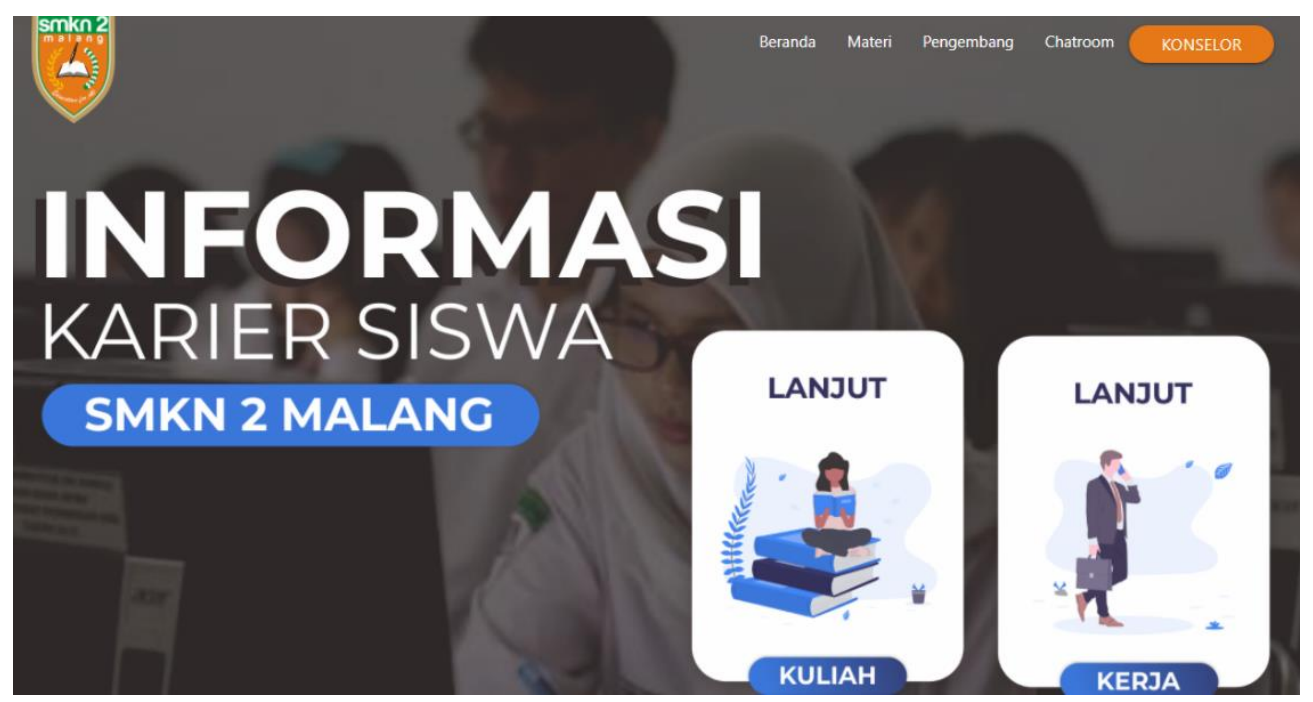

Gambar 1. Halaman Website

Produk ini telah mendapat validasi oleh dua ahli materi BK, validasi dua ahli media, serta validasi dari dua orang konselor SMK sebagai calon pengguna produk.

Hasil indeks penilaian dari data kuantitatif dengan inter-rater agreement model yang diperoleh dari dua ahli Bimbingan dan Konseling, dua ahli media, dan dua calon pengguna produk (konselor). 
Jurnal Pembelajaran, Bimbingan, dan Pengelolaan Pendidikan, 1(1), 2021, 11-20

Tabel 3. Inter-rater Agreement Model Validasi Ahli Materi Bimbingan dan Konseling

\begin{tabular}{cccc}
\cline { 3 - 4 } & & \multicolumn{2}{c}{$\begin{array}{c}\text { Pendapat Ahli dan Calon Pengguna } \\
\text { Produk (1) }\end{array}$} \\
\cline { 2 - 4 } & & $\begin{array}{c}\text { Relevansi } \\
\text { Rendah (1-2) }\end{array}$ & $\begin{array}{c}\text { Relevansi } \\
\text { Tinggi (3-4) }\end{array}$ \\
\hline $\begin{array}{c}\text { Pendapat Ahli dan } \\
\text { Calon Pengguna Produk } \\
\text { (2) }\end{array}$ & Relevansi Rendah (1-2) & 0 & 0 \\
\cline { 2 - 4 } & Relevansi Tinggi (3-4) & 0 & 24 \\
\hline
\end{tabular}

Berdasarkan hasil inter-rater agreement, maka indeks validitas konten website, sebagai berikut.

$$
\text { Indeks Validasi Ahli }=\frac{D}{A+B+C+D}=\frac{24}{0+0+0+24}=1
$$

Indeks validasi ahli materi BK diperoleh skor "1" yang berarti konten website tentang informasi karier berbasis $4 C^{\prime}$ 's memiliki validitas yang sangat tinggi. Sehingga keberterimaan produk konten website juga tinggi.

Tabel 4. Inter-rater Agreement Model Validasi Ahli Media

\begin{tabular}{|c|c|c|c|}
\hline & & \multicolumn{2}{|c|}{$\begin{array}{c}\text { Pendapat Ahli dan Calon Pengguna } \\
\text { Produk (1) }\end{array}$} \\
\hline & & $\begin{array}{c}\text { Relevansi } \\
\text { Rendah (1-2) }\end{array}$ & $\begin{array}{l}\text { Relevansi } \\
\text { Tinggi (3-4) }\end{array}$ \\
\hline \multirow{2}{*}{$\begin{array}{c}\text { Pendapat Ahli dan } \\
\text { Calon Pengguna Produk } \\
(2)\end{array}$} & Relevansi Rendah (1-2) & 0 & 0 \\
\hline & Relevansi Tinggi (3-4) & 0 & 22 \\
\hline
\end{tabular}

Berdasarkan hasil inter-rater agreement, maka indeks validitas konten website, sebagai berikut.

$$
\text { Indeks Validasi Ahli }=\frac{D}{A+B+C+D}=\frac{22}{0+0+0+22}=1
$$

Indeks validasi ahli media diperoleh skor "1" yang berarti konten website tentang informasi karier berbasis 4C's memiliki validitas yang sangat tinggi. Sehingga keberterimaan produk konten website juga tinggi. 
Jurnal Pembelajaran, Bimbingan, dan Pengelolaan Pendidikan, 1(1), 2021, 11-20

Tabel 5. Inter-rater Agreement Model Validasi Ahli Media

\begin{tabular}{cccc} 
& & \multicolumn{2}{c}{$\begin{array}{c}\text { Pendapat Ahli dan Calon Pengguna } \\
\text { Produk (1) }\end{array}$} \\
\cline { 2 - 4 } & & $\begin{array}{c}\text { Relevansi } \\
\text { Rendah (1-2) }\end{array}$ & $\begin{array}{c}\text { Relevansi } \\
\text { Tinggi (3-4) }\end{array}$ \\
\hline $\begin{array}{c}\text { Pendapat Ahli dan } \\
\text { Calon Pengguna Produk } \\
\text { (2) }\end{array}$ & Relevansi Rendah (1-2) & 0 & 0 \\
\cline { 2 - 4 } & Relevansi Tinggi (3-4) & 0 & 38 \\
\hline
\end{tabular}

Berdasarkan hasil inter-rater agreement, maka indeks validitas konten website, sebagai berikut.

$$
\text { Indeks Validasi Ahli }=\frac{D}{A+B+C+D}=\frac{38}{0+0+0+38}=1
$$

Indeks validasi calon pengguna produk (konselor) diperoleh skor "1" yang berarti konten website tentang informasi karier berbasis 4C's memiliki validitas yang sangat tinggi. Sehingga keberterimaan produk konten website juga tinggi.

Selain mendapatkan hasil data kuantitatif, produk juga mendapatkan penilaian dari data kualitatif. Data kualitatif diperoleh dari saran atau masukan dari ahli materi BK, ahli media, dan calon pengguna produk (konselor). Pengembang telah melakukan reduksi data, penyajian data dan penarikan kesimpulan, lalu memberikan hasil melalui model Miles dan Huberman sebagai berikut : a) Penggunaan beberapa kalimat perlu diperbaiki; b) RPL-BK kurang lengkap, yakni pada rumusan tujuan khusus yang belum mencerminkan pencapaian 4C's bagi siswa dan kegiatan inti masih umum belum spesifik; c) Pada konten website sebaiknya ditambah dengan penjelasan pengantar, berupa 2-3 paragraf seputar dunia kuliah dan dunia kerja; d) Website akan lebih menarik apabila ditambah fitur fasilitas kontak berupa chatroom demi memudahkan komunikasi antar siswa dan konselor; e) Penggunaan icon page website dipastikan free to use agar tidak melanggar hak cipta, demi menghindari masalah dikemudian hari; f) Warna yang terlalu mencolok atau terlalu kuat sebaiknya diganti dengan warna yang lebih netral; g) Secara umum, konten ini sudah menarik, keren dan luar biasa, telah sesuai dengan notabennya siswa SMK yang membutuhkan informasi dunia kerja dan dunia kuliah serta produk ini cocok digunakan ketika masa pandemi; h) Apabila penggunaan nama baru dirasa membuat siswa bingung karena banyak siswa yang masih familiar dengan nama lama, maka dalam website lebih baik keduanya sama-sama disebutkan. Misal jalur masuk politeknik yakni PMDK-PN dan UM-PN, tahun 2020 ini diganti dengan SNMPN dan SBMPN.

\subsection{Pembahasan}

Penelitian dan pengembangan ini menghasilkan konten website tentang informasi karier berbasis 4C's bagi siswa SMKN 2 Malang. Pengembang juga menetapkan laman "bkmillenial.com" sebagai produk akhirnya. Konten website tentang informasi karier ini telah melalui dua tahapan validasi yaitu validasi ahli dan validasi lapangan. Tahap validasi ahli dilakukan oleh Ahli Materi Bimbingan dan Konseling dan Ahli Media, masing-masing 2 orang. 
Sedangkan validasi lapangan dilakukan oleh 2 orang Calon Pengguna Produk (Konselor). Pelaksanaan validasi ahli dan validasi lapangan didasarkan pada pernyataan penting adanya kelayakan validasi ahli dalam mengetahui konsep dasar atau teori yang digunakan serta validasi lapangan dalam mengetahui kelayakan secara praktis (Sukmadinata, 2013). Penilaian konten website ditinjau dari segi ketepatan, kegunaan, kemudahan serta kemenarikan yang diperoleh skor "1" dalam rentang 0,75-1 yang berarti bahwa konten website tentang informasi karier berbasis 4C's memiliki keberterimaan produk yang sangat tinggi, sehingga sangat layak digunakan oleh konselor dalam memberikan layanan bimbingan.

Pengembang melaksanakan need assessment terhadap siswa dan wawancara terhadap konselor untuk mengetahui metode penyampaian informasi yang selama ini digunakan oleh konselor dan mengetahui tingkat pemahaman siswa terkait informasi karier terutama pada lanjut kuliah dan lanjut kerja. Penyebaran need assessment (angket kebutuhan) terhadap siswa dan wawancara terhadap konselor sangat berperan penting sebagai analisis kebutuhan di sekolah dalam merumuskan juga menyempurnakan konten website sehingga menghasilkan produk yang dapat memudahkan siswa dalam menerima layanan informasi karier di sekolah. Angket kebutuhan (need assessment) dan wawancara merupakan pengumpulan informasi awal sebagai landasan gagasan atau ide bagi penelitian pengembangan ini.

Pemilihan konten website tentang informasi karier berbasis 4C's dinilai sangat tepat karena siswa mempunyai bekal pengetahuan lebih untuk menghadapi dunia kerja maupun dunia kuliah sebagai kelanjutan karier yang akan dipilih. Hal ini sangat sesuai dengan pernyataan yang menyebutkan bahwa umumnya layanan informasi karier yang diberikan kepada siswa SMK yakni memasuki dunia kerja dan melanjutkan kuliah ke Perguruan Tinggi Negeri atau swasta (Prayitno, 2004). Oleh sebab itu, siswa dapat menyesuaikan diri dengan pilihan pekerjaan serta pilihan program pendidikan.

Menurut Zubaidah (2016), demi mempersiapkan pribadi yang sukses terutama dalam berkarier perlu adanya proses dalam kegiatan belajar, hal ini juga pasti mengandung beberapa keterampilan khusus yang harus dimiliki setiap generasi millenial. Keterampilan yang diterapkan dalam kehidupan sehari-hari ini yakni keterampilan 4C's, mencakup critical thinking and problem solving (keterampilan berpikir kritis dan menyelesaikan masalah), creative thinking and innovation (keterampilan berpikir kreatif dan inovasi), collaboration (keterampilan kolaborasi) and communication (keterampilan komunikasi). Adanya keterampilan 4C's pada penelitian pengembangan ini adalah sebagai bentuk evaluasi setelah menerima materi serta dapat mencerminkan pencapaian 4C's di kehidupan sehari-hari siswa.

Produk konten website tentang informasi karier juga dinilai cukup menarik dan bagus dari segi tampilan, warna, fitur hingga desain, dikarenakan pengembang telah menyesuaikan dengan karakteristik siswa SMK ataupun generasi millenial saat ini yang tidak bisa jauh dengan namanya internet. Hal ini sejalan dengan pendapat Hendrianto (2014: 59) mengungkapkan bahwa internet merupakan interkoneksi antar jaringan pada komputer, yang secara umum dipandang sebagai sumber daya informasi dalam bentuk dunia maya. Karena hampir seluruh aspek di dunia nyata ada didalam internet. Internet juga merupakan singkatan dari Interconnected Network. Dengan kata lain, dapat disebutkan bahwa internet yakni sistem komunikasi yang mampu menghubungkan seluruh jaringan pada komputer di dunia ini.

Pertama, Ari Murdiyanto, Edi Purwanta dan Kamaruddin melakukan penelitian mengenai layanan informasi karier berbasis media blog untuk meningkatkan eksplorasi karier 
siswa di SMP Kota Magelang pada tahun 2017. Dari penelitian yang dilakukan akhirnya diperoleh kesimpulan bahwa dengan adanya media blog, eksplorasi karier siswa meningkat. Hal ini ditunjukkan pula memberikan kemudahan kepada konselor dalam memberikan layanan informasi karier kepada siswa SMP. Kedua, Dwi Anita Agustina melakukan penelitian demi menghasilkan paket layanan informasi studi lanjut pada sekolah kedinasan bagi siswa SMA pada tahun 2015. Dari penelitian yang dilakukan akhirnya diperoleh kesimpulan bahwa informasi sekolah kedinasan bisa didapatkan pada paket layanan informasi yang sangat berguna bagi siswa SMA dalam menambah wawasan atau pengetahuan lebih luas lagi. Ketiga, Trisma Sulyganistia melakukan penelitian mengenai penerapan layanan informasi karier dengan menggunakan media flashcard untuk meningkatkan kemantapan perencanaan karier siswa kelas XI SMA Negeri 11 Surabaya pada tahun 2013. Dari penelitian yang dilakukan akhirnya diperoleh kesimpulan bahwa media flashcard mampu memantapkan perencanaan karier siswa SMA meningkat. Hal ini ditunjukkan pula dengan penerapan layanan informasi ini sangat efisien dilaksanakan ketika bimbingan karier pada jam BK.

Hasil penjelasan teori dan hasil penelitian terdahulu sejalan dengan menunjukkan bahwa pengembangan ini mampu menghasilkan konten website tentang informasi karier berbasis 4C's bagi siswa SMKN 2 Malang, yang berterima secara teoritik dan praktis berdasarkan aspek ketepatan, kegunaan, kemudahan dan kemenarikan. Penelitian terdahulu dengan penelitian ini yang membedakan adalah yang terletak pada subjek (jenjang atau tahapan pendidikan), objek (materi atau konten yang diteliti), dan produk atau media yang dikembangkan sebagai bentuk layanan BK bagi siswa dan konselor di sekolah. Gagasan ide dalam penelitian ini juga berdasarkan hasil wawancara dengan konselor serta adanya hasil observasi di sekolah yang telah disesuaikan dengan angket kebutuhan (need assessment).

Produk ini pastinya memiliki beberapa kelebihan dan kekurangan. Kelebihan yang dimiliki, yakni : 1) konten website tentang informasi karier dikembangkan berdasarkan need assessment yang telah dilakukan oleh pengembang, sehingga sesuai dengan kebutuhan siswa; 2) konten website tentang informasi karier telah melalui validasi ahli materi BK, validasi ahli media serta calon pengguna produk (konselor), sehingga produk yang dihasilkan telah berterima secara teoritis, praktis, efisien dan memiliki manfaat bagi penggunanya; 3) konten website tentang informasi karier memiliki beberapa daya tarik dari segi tampilan, icon, warna, fitur, maupun desain, sehingga menarik perhatian siswa untuk menggunakannya dan memahami informasi karier dengan baik. Sedangkan kelemahan konten website, yakni: 1) penggunaan konten website ini hanya dapat digunakan secara online pada layar PC atau laptop, sehingga sangat memerlukan sedikit modal kuota paketan internet atau wifi ; 2) terdapat sepuluh langkah-langkah penelitian dan pengembangan yang telah dikemukakan oleh Borg \& Gall, namun tidak semua dilakukan oleh pengembang karena adanya keterbatasan waktu, sehingga belum diketahui keefektifannya.

\section{Simpulan}

Produk pengembangan menghasilkan konten website tentang informasi karier berbasis 4C's bagi siswa SMKN 2 Malang yang dikembangkan telah memenuhi dari validasi ahli materi BK, ahli media dan calon pengguna produk (konselor) yang semua dilakukan oleh masng-masing dua orang. Hasil penilaian tersebut menyatakan bahwa keberterimaan produk sangat tinggi, sehingga layak digunakan dalam pemberian layanan Bimbingan dan Konseling. Saran ditujukan untuk konselor yaitu diharapkan mempelajari sebelum melaksanakan layanan informasi menggunakan konten website secara prosedural yang 
telah tertulis jelas tahapan kegiatan dan tujuannya dalam RPL-BK serta terdapat infografis pada halaman awal website sebagai panduan penggunaan konten website. Hal ini bertujuan agar konselor menggunakan website secara efektif, begitupula dengan siswa agar lebih mendalami informasi karier tentang lanjut kuliah dan lanjut kerja. Saran bagi peneliti selanjutnya, untuk melakukan eksperimen untuk mengetahui keefektifan konten website guna memperoleh hasil lebih akurat. Selain itu, dapat melalui penelitian pengembangan kembali, namun dikombinasikan dengan model ataupun teori baru sehingga lebih menarik dan ditambah konten website nya agar lebih lengkap.

\section{Daftar Rujukan}

Afandi, M. (2011). Tipe Keribadian dan Model Lingkungan dalam Perspektif Bimbingan Karier John Holland. Sosial Budaya, 8(1), 86-96.

Agustina, D. A. (2015). Pengembangan paket layanan informasi studi lanjut pada sekolah kedinasan bagi siswa SMA. SKRIPSI Jurusan Bimbingan dan Konseling \& Psikologi-Fakultas Ilmu Pendidikan UM.

Gall, W. R., \& Borg, M. D. (1983). Educational research: An introduction. Longman Publishing.

Gregory, R. J. (2000). Psychological testing: History, principles, and applications. Allyn \& Bacon.

Hakim, L., \& Musalini, U. (2004). Cara Cerdas Menguasai Layout, Desain dan Aplikasi Web. Jakarta: PT Elex Media Komputindo.

Hendrianto, D. E. (2013). Pembuatan Sistem Informasi Perpustakaan Berbasis Website Pada Sekolah Menegah Pertama Negeri 1 Donorojo Kabupaten Pacitan. IJNS-Indonesian Journal on Networking and Security, 4(3), 57-64.

Kamaluddin, H. (2011). Bimbingan dan konseling sekolah. Jurnal Pendidikan dan Kebudayaan, 17(4), 447-454.

Murdiyanto, A., Purwanta, E., \& Kamaruddin, K. (2018). Pengembangan Layanan Informasi Karier Berbasis Media Blog Untuk Meningkatkan Eksplorasi Karier Siswa di SMP Kota Magelang. JBKI Jurnal Bimbingan Konseling Indonesia), 2(2), 40-46.

Prayitno \& Amti, E. (2004). Dasar-dasar Bimbingan dan Konseling. Jakarta: Rineka Cipta.

Sugiyono, (2014). Memahami Penelitian Kualitatif. Bandung: CV. Alfabeta

Sukmadinata, N. S. (2013). Metode Penelitian Pendidikan. Bandung: PT Remaja Rosdakarya.

Sulyganistia, T. (2013). Penerapan Layanan Informasi Karier dengan Menggunakan Media Flashacard untuk Meningkatkan Kemantapan Perencanaan Karier Siswa Kelas XI SMA Negeri 11 Surabaya. Jurnal BK Unesa, 3(1).

Zubaidah, S. (2016, December). Keterampilan abad ke-21: Keterampilan yang diajarkan melalui pembelajaran. In Seminar Nasional Pendidikan (Vol. 2, No. 2, pp. 1-17). 